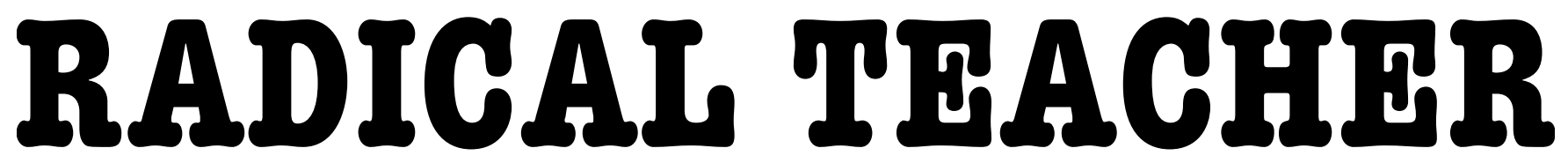

A SOCIALIST, FEMINIST, AND ANTI-RACIST JOURNAL ON THE THEORY AND PRACTICE OF TEACHING

\title{
White Fears of Dispossession: Dreyer's English, The Elements of Style, and the Racial Mapping of English Discourse
}

by Laura Lisabeth

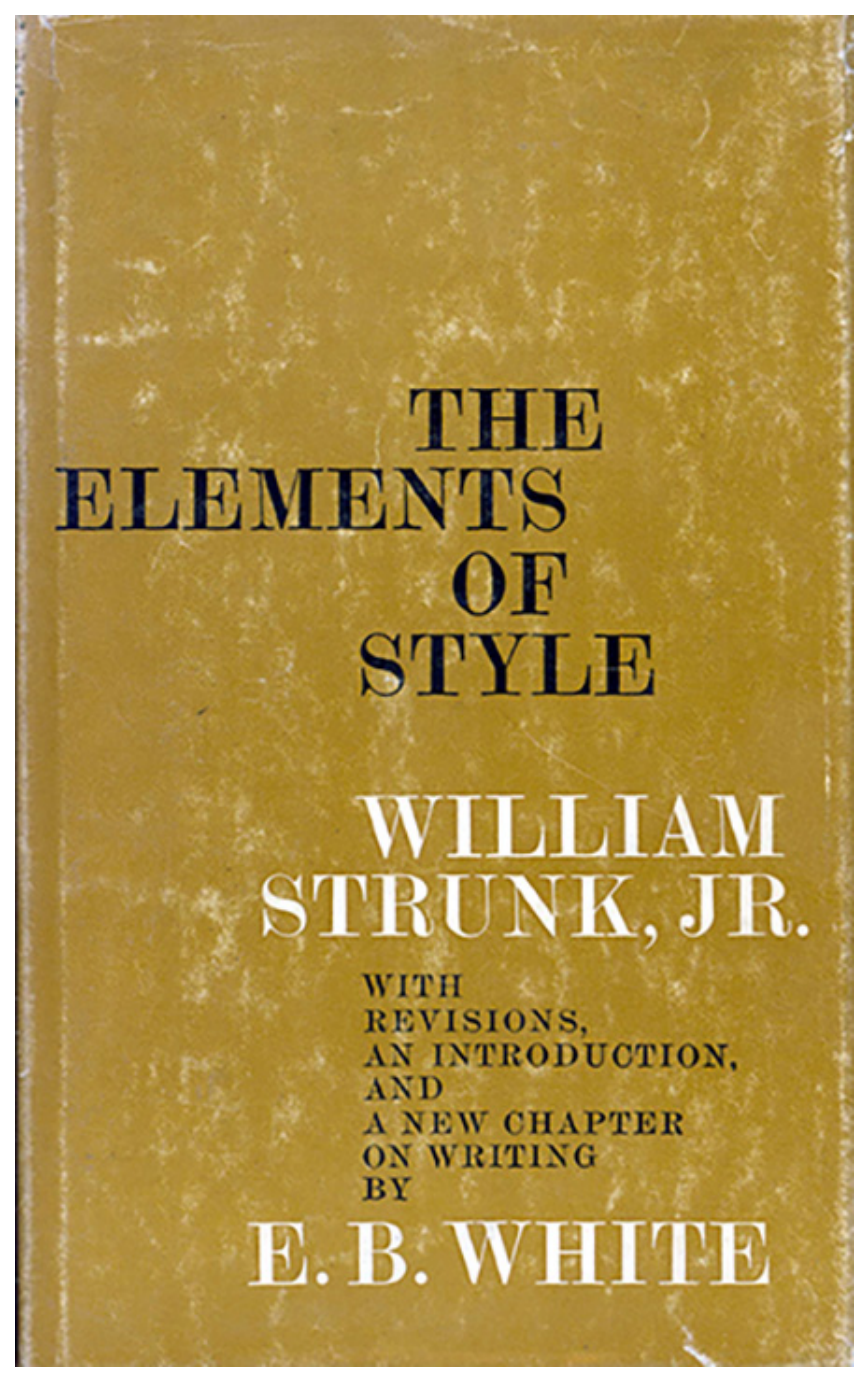

STRUNK, WILLIAM JR., AND E. B. WHITE, THE ELEMENTS OF STYLE, THE MACMILLAN COMPANY, 1959. 
When I look at a movement that hungers for recognition from the very people who disown us $I$ remember that we are grieving.

\section{- Alok Vaid-Menon}

Dreyer's English: An Utterly Correct Guide to Clarity and Style (Random House, 2019) by Benjamin Dreyer, Random House's Senior Copy Editor, enters a ring long dominated by the perennial Strunk and White's The Elements of Style. Dreyer's book is currently number two on three Amazon book lists, right next to Strunk and White, who have been firmly at number one on many such lists, some that pre-date Amazon, since its first edition was published by Macmillan in 1959. This review will argue that both The Elements of Style and Dreyer's English are emblematic of the underinterrogated systemic racism of standardized English, and that this has far-reaching implications when these texts find their way into writing curricula. Some of those implications include the racist impact of program and institutional choices to make standardized English style part of assessment practices (Inoue 2015) resulting in the implicit underwriting of White Supremacist language as it is valued in discursive style guides such as Dreyer's or Strunk and White's. Writing classrooms that include Dreyer's English or The Elements of Style or any of a number of other pundit-driven writing handbooks take up the project of constructing English as White property instead of searching for ways to welcome other language epistemologies, and to step aside for long-overdue acts of resistance that come with reappropriating the discourse of power, especially within the institutions that have historically reproduced a social and economic order that benefits White Americans.

Asao Inoue reminds us that both schools and literacy have historically been constructed to protect White Supremacy. He calls attention to the work of Catherine Prendergast and Cheryl L. Harris who both use legal accounts to illustrate the history of literacy as White property (Harris 1993, Prendergast 2003). He also ties this history of the Whiteness of literacy to the early twentieth century eugenicist Lothrop Stoddard, who warned of "White Settlements" being populated by people of color in his 1920 book The Rising Tide of Color: The Threat Against White World Supremacy. Inoue writes of Stoddard's concept of "inner dikes," historically formed social institutions that are "bulwarks" of Whiteness:

Just like the logic behind redlining to protect real estate property from Black Americans, the White settlemen ts-the White property-that Stoddard speaks of are understood as crucial dikes that need protecting because they are the last defense of the White centers. Education, schools, and literacy in the US are inner dikes. (Inoue 11)

The implications of continuing to pay forward this American tradition of cherishing usage guides that express racialized language idiosyncrasies sediments another kind of oppressive layer into the already untenable realities for people of color in American educational, social and economic spaces. We continue to be a society that is reluctant to recognize how educational systems have persisted in functioning as inner dikes of Whiteness.

Writing in The Nation, Kyle Paoletta frames Dreyer's book in terms that underscore the systemic nature of the racism driven by standardized English when he observes, "Dreyer's English is a style guide for the one percent." Like E.B. White before him, Dreyer promotes a historically classed, racialized and gendered code, that of the privileged White man alert to dispossession, who patrols the boundaries of a White system of knowledge production.

The genre Dreyer has inherited from White-a kind of idiosyncratic narrative of correct language usage-can be partly traced all the way back to changes in rhetorical education at the end of the nineteenth century. Robert J. Connors describes this period as a "transition from emphasis on style and communicative effectiveness to primary emphasis on rule-governed mechanical correctness" (87), and Dreyer does his part to regulate commas. But to understand the particular historical roots of Dreyer's English and The Elements of Style, we must look at an earlier predecessor that comes closer to capturing what these two popular books are up to. In "Handbooks: History of a Genre" (1983), Connors looks even further back in history to a change in America's social structure and the writing handbook's more revealing ancestor from the mid-nineteenth century, the "handbook of conversation," a genre of popular ettiquette guides (87). It is this family tree to which Dreyer and E.B. White belong. Rather than prescribing mechanical correctness like the ones that began their hegemonic rule in the late nineteenth- and earlytwentieth centuries along with current-traditional rhetorical instruction, Dreyer and White create discursive maps of social, racial and gendered territory that are so seductive they reign on bestseller lists for years-sixty, in fact, in the case of The Elements of Style.

The antecedents for White's and Dreyer's books are out of a specific American social history deeply marked by moral anxiety. Cultural historian Karen Halttunen describes American antebellum society as a landscape of shifting class and moral boundaries as "young men were leaving their rural homes and families to seek work in the booming cities of industrializing America. As thousands of young Americans 
broke away from traditional restraints on their conduct, middle-class moralists began to grow alarmed" (Halttunen 1 ). Connors aligns this period of American history with a proto-genre of handbooks that were "manuals of usage, politesse, and manners [that] became increasingly popular as the social equalitarianism of the Jefferson-Jackson period receded in America." (87). So, Connors points out, these "conversation" handbooks were "the products of cultural rather than of pedagogical needs" (ibid.) In Authority in Language, Milroy and Milroy write that after the Civil War, language ideology in America focused on racial discrimination rather than on class distinctions (160), a uniquely American form of language prejudice. During this period, conversation and etiquette handbooks began to appear to demonstrate social behavior and language as racial territories with rules and boundaries that must be policed not just in the interests of middle-class-gentility but against racial incursion. Titles like Don't and Discriminate (Connors 87 ), both published in 1883 , remind us that some of these behavior guides coincided with the Reconstruction era, and were filled with a kind of White Supremacist outrage against social, cultural and economic dispossession, a telltale mark of White Supremacy, as Eduardo Bonilla-Silva discusses in detail in his book, Racism Without Racists (2014). This territorial quality of White Supremacy plays out in proprietary attitudes toward English language as a kind of property as well; Bonilla-Silva might see this linguistic propriety in an educational context as one of the "frames of abstract liberalism" used in this case to rationalize meritocratic beliefs about the teaching of standardized English. Asao Inoue, whose anti-racist writing pedagogies and assessment practices are some of the most important recent developments in the field of Composition, similarly calls out dominant language standards as racist by saying that "all grading and assessment exist within systems that uphold singular, dominant standards that are racist and White Supremacist when used uniformly" (Labor Based 3). Connors cites an 1847 Grammatical Corrector by Seth Hurd, in which Hurd recruits his reader in defense of English language territory by telling her what the linguistic invaders are: "a collection of nearly two thousand barbarisms, cant phrases, colloquialisms, quaint expressions, provincialisms, false pronunciation, perversions . . . and other kindred errors of the English language" (ibid.) This is where Dreyer's English and The Elements of Style belong-not so much next to the classroom or office usage handbook, although they do function in part as quick usage references-but to this genre, the discursive guide to linguistic respectability as White territory. When reading Dreyer's thoughts about lawlessness, crossbreeding and invasion of Anglo Saxon culture inherent in the history of English, it would seem that a scant few days have passed since Hurd made his pronouncements in the Grammatical Corrector. Dreyer writes:

The English language...is not so easily ruled and regulated. It developed without codification, sucking up new constructions and vocabulary every time some foreigner set foot on the British Isles-to say nothing of the mischief we Americans have wreaked on it these last few centuries...It has, to my great dismay, no enforceable laws, much less someone to enforce the laws it doesn't have (6).
Dreyer's reference to law enforcement as a response for sullied English smacks of Jim Crow Era policing of imagined transgressions of White boundaries. Halttunen describes similarly racialized mid-nineteenth-century performances of social boundaries as "polite social geography" in which the decorated and arranged front rooms of the house hid the messy social relations of the servant areas, such as the kitchen (102). The rules for staging one's behavior within the bounds of these social spaces were spelled out in rigid prescriptions for the body that included how to carry gloves or hats, or where to stand while talking with a party guest. Guides such as The Young Man's Friend (1855), included excruciatingly prescriptive instructions for crossing the threshold of someone's house:

"If an appointment had been made, the visitor was to stand at the door as the clock chimed the hour: '...your body must be in a right line with the frame of the door at the instant the first stroke of the great clock sounds. If a moment later, your character is gone'" (Martine qtd. in Haltunnen 102).

For both Dreyer and White language becomes the ground upon which social relations are mapped according to a similar linguistic system of racialized parlor and kitchen geography. For Dreyer, using trendy nominalizations, such as "that's a big ask," constitutes the kind of linguistic stumble that literally unmasks the writer, communicating to everyone in the parlor that you belong in the back of the house: "[nominalizations] grate as well as amuse, as can many of the other attempts...to gussy up shopworn ideas by replacing conventional language with overreaching-and arguably unnecessary-coinages" (Dreyer 150). Dreyer's use of "overreaching" broadcasts his opinion that language usage reveals the speaker's origins, dividing those who speak the code of the parlor from those who don't. In White's case, though he, too, wants trendy vocabulary kept out of the front parlor. He concedes-like the duplicitous Victorian he is - that a writer can secret it away in the kitchen: "Buy the gold-plated faucets if you will, but do not accessorize your prose" (White 82). Our history of systemic moral turpitude toward race, class and middle-class values, and the nineteenth-century conversation guides originally designed to resolve these anxieties, can help us to think about the ways our modern-day discursive guides to language similarly maintain systemic racism in deeply historical and uniquely American ways. These kinds of dicta are, as Carmen Kynard points out, simply the "aesthetic rules of a white middle class" (4).

\section{For both Dreyer and White language becomes the ground upon which social relations are mapped according to a similar linguistic system of racialized parlor and kitchen geography.}

Going back sixty years to the 1959 formation of the Elements of Style, we can see that White, represented by Macmillan, then one of the last of the old patrician family publishing firms, voices the same fears of dispossession 
Dreyer expresses. White's boundary-tending materializes in the racist imagery of twentieth-century imperialism. English has disturbingly fragile borders, and writers must not be lured into any transgression that might take them into uncivilized country. To transgress correctness becomes an existential threat in these terms, and when this disposition is transferred to the writing classroom, primarily students who have not grown up using standardized English see their lives hinged to their ability to perform it. For example, White sees in the wider culture "a mainstream of turbulence" and "the beat of new vocabularies," and he warns the writer to "not be carried away" (68). Such metaphors of angry waters and strange languages sounding like drums call up images of a colonial time in which Whiteness stood for the stabilizing effect on the world of Empire's "civilizing" presence. Perhaps Dreyer's colonial disposition toward language is most visible through its embeddedness in the world of publishing and popular literacy: the websites, podcasts, blogs and Twitter streams that propagate these racialized and classed beliefs about language, one being that some among us have an "ear" for what's correct, a kind of inborn sense about "what works" in a sentence, as Dreyer says (lithub.com 2019). White, too, sees "style" as intuitive, as a constellation of "high mysteries," in fact (White 52). This is an expression of White habitus plain and simple (see Inoue Labor-Based, chap. 1). Both Dreyer and White, when talking about usage and style, sound a lot like they are defending the "inner dikes" of Whiteness that Inoue describes. Like The Elements of Style, Random House's Dreyer's English began its life on top of bestseller lists, proving that those inner dikes include the publishing industry. Most troubling are the racist dispositions hidden away in such writing advice and baked into American educational culture where complaining about the lack of standardized correctness in student writing is an ever-present conversation, part of a paternalistic and racialized vision of teaching writing.

\section{Most troubling are the racist dispositions hidden away in such writing advice and baked into American educational culture where complaining about the lack of standardized correctness in student writing is an ever-present conversation, part of a paternalistic and racialized vision of teaching writing.}

As a twenty-first century guide to linguistic gentility, Dreyer's English has a partly self-selecting readership: readers, Kyle Paoletta points out, that prove Dreyer's book is "destined only to confirm to the snobs and sycophants who will doubtlessly cherish it that they really are smarter than the rest of us" ("A Style Guide"). But, The Elements of Style is deeply entrenched in higher education, and appears on a surprising number of syllabi across the disciplines, suggesting that not all readers are independently choosing to consult the book. In fact, it is the number one mostassigned textbook across over a million syllabi according to The Open Syllabus Project (opensyllabusproject.org), put there by otherwise well-meaning professors from all disciplines with the hope that the book will magically transform student writing into expert academic prose, or at least cure a few incoherencies, perhaps help corral the "offbeat," as White would have preferred. The privileged language of the academy has in fact grown out of this history of gentility with its anxieties over class and racial boundaries and has become, as Asou Inoue suggests, "[w]hiteness as a discourse and set of expectations in writing" (Antiracist 49). As a naturalized part of educational culture, Standardized English is foregrounded, Carmen Kynard points out, even in institutions that insist on its primacy "alongside a rhetoric of dismantling" hegemonic discourse (Kynard, italics original, 19). This persistent hypocrisy is disheartening; for radical teachers, it is a focus for resistance, as it preserves Standardized English as "one of the mechanisms of structural racism" in education (Howard 2018).

When we support standardized English as the primary and desired discourse for all students-all people who arrive here in American and want to stay, work or study- we buy into its classed and racialized code upon which the teaching of writing has historically based its ethos and conducted its practices. What constitutes "good" English style in academic settings is formed by a complex ecology of institutional, cultural, and consumerist forces which, across history, have supported Standardized English for profit by exploiting its nearly mythical connections to an aspirational figment of the social imagination: the literate White American, exquisitely performed by both Dreyer and White. In 1959 Macmillan marketed The Elements of Style as a partner in the national construction of academic discourse that a Cold War Congress was busy mandating and funding along with other monocultural, monolingual education features underwritten by the National Defense Education Act (1958). Today, the ties between education and global corporate culture might make us long for a new NDEA-government support that would sustain education against a new and ironic set of enemy interests that include its own Secretary of Education who funnels public education funds into private schools. Henry Giroux sees current neoliberal corporate pressure on schools as a drive toward "pure instrumentalism," resulting in starved humanities budgets as part of a broader culture war in which the rise of the corporate university has become a "sustained effort to dismantle education from the discourse of democracy, public values, critical thought, social responsibility, and civic courage" (Giroux 31). For the radical teacher, it is important to know that books like Dreyer's English and The Elements of Style perpetuate the American meritocratic myth that says education and a command of Standardized English will help students transcend social and racial barriers without examining the systems that create those barriers in the first place. The prospect of meritocracy in America was never true even though it has become an entrenched narrative that purports to be a cornerstone of American democracy. The strikingly similar ironic tone deployed by both White and Dreyer is a cynical hedge against the historical fact that a socially configured correct English does not hand those students the "keys to glory," as Carmen Kynard, in a stroke of more ethically grounded irony, names the empty meritocracy of standardized language acquisition (4). 
In their irony Dreyer and White may sound like they really know better, but they are too comfortable with their racial and class affiliations. Their cynical language dispositions travel beyond classrooms and cocktail parties and are behind profits to publishers and other global corporations that exploit Standardized English as the lingua franca of not only American social access but of domestic and world business as well, growing the reach of a privileged white code and deepening its already long history of false promises and racism. Contingent to the American meritocracy myth is the global workplace where English language is a commodity impacting millions of workers who view the acquisition of "business English" as imperative to earning a place in the world economy.

Language as a parlor game for the one percent takes on significant ethical complications when placed in the context of the global workplace where English has been co-opted by neoliberal language values. "Neoliberal linguistics," as defined by Suresh Canagarajah, is a term that captures the exploitation of language as "product," as in his example of a Japanese restaurant in Tunisia that "uses Japanese-looking scripts, which are actually undecipherable and don't mean anything" (15). But it also affects the workers who use English in the multi-national corporate world, such as the people he interviews in his book, African Skilled Migrants in Anglophone Workplaces, who see English as a way to economic mobility but discover that " $\mathrm{t}]$ hough the promotion of English is presented as a way of expanding one's multilingual resources, it reduces one's repertoire, as it is often learned/taught at the cost of local languages" (13). However, Canagarajah goes on to argue for the ever-present resistance of translingual resources:

"though monolingualism and uniformity are enforced by gate keepers and the powerful, translingual scholars are optimistic that spaces can be found for variation in the mix of semiotic resources that constitute a text...The diversity that always exists in practice enables multilingual communities to find spaces for voice, renegotiation, and resistance" (56).

The same empowering argument can be made for the writing classroom, too; in particular, as Canagarajah's work shows, neoliberal linguistics is an area for more research in professional and technical writing. In these professional and technical writing classrooms, in which students are often presented the code of gatekeeping and power as a decontextualized discourse of correctness tied to their economic life, we can design opportunities to see the historical context of correct and standardized notions of English language, while honoring students' own language resources. As Inoue writes, we need to name the effects of English:

"our students are in our classrooms to learn rhetorical practices that will help them as citizens who must language in the world. They need us for this work. It is also a critical learning of a White racial habitus, or maybe a learning of ways to be mad against it and the institutional systems that reproduce White language privilege" (Labor-Based 48).
Inoue's critical framing of standardized English is where I center my writing pedagogy. A rhetorical analysis of Dreyer's or Strunk and White's texts is a good place to start generating these essential critical questions about the historical role of English. In keeping with Inoue's antioppressive pedagogies, there are some teaching practices I have started to develop that generate a few "ways to be mad" at oppressive language standards. My chapter, "Empowering Education With Social Annotations and Wikis" in the edited collection Web Writing: Why And How For Liberal Arts Teaching (2015), shares the results of an assignment in which I asked a class of Introduction to English Studies students to analyze the rhetoric of The Elements of Style. They worked in small groups using a hosted wiki, but a google document shared with everyone is a more streamlined alternative that students are more generally familiar with. Breaking apart the text into lexical pieces of their choice, students were asked to first analyze the rhetoric of the passage, and then to create a collaborative imaginative and multimodal response to that rhetoric, using language, creative typography, images, short videos and gifs or original artwork. As traditional English Studies majors, many students engaged in the rhetoric as fans of language correctness. But some also took the opportunity to question White's pronouncements and call attention to suggestions like, "Place yourself in the background," a directive to background identity in favor of the "sense and substance of the writing" (56); in the context of The Elements of Style, this is a move toward the white language identity of the academy.

To situate the college writing classroom in critical space, every semester I assign readings from the anthology Rotten English (ed. Dohra Ahmad 2007), a collection of vernacular English literature from around the world. This literature allows us to discuss English on the global stage, and through the lens of systemic power structures. Combining the history of the English Education Act (1835) described in the contemporaneous "Macaulay's Minute On Indian Education" with the vernacular poetry and fiction of writers from former Euroamerican colonies, students gain a critical understanding of the language of power and the power of language identities that over history have bent the English standard with non-standard knowledge. Many institutions expect students to perform standardized English and academic genres that privilege a white knowledge system, but "languaging in the world," as Inoue says, paired with discussions of English as a colonizing force overthrown beautifully, passionately by artists like Mutabaruka, Kendrick Lamar or Patricia Grace, gives students empowering and creative alternatives. It is not enough, however, to hold these literate gestures up as a resistant preamble to what school presents as the more important business as usual of learning the White standard. 


\section{Works Cited}

Ahmad, Dohra, editor, Rotten English: A Literary Anthology, Norton, 2007.

Bonilla-Silva, Eduardo. Racism Without Racists: Color-Blind Racism and the Persistence of Racial Inequality in the United States, Rowman \& Littlefield, 2006.

Canagarajah, Suresh, Translingual Practices and Neoliberal Policies: Attitudes and Strategies of African Skilled Migrants in Anglophone Workplaces, Springer, 2017.

Connors, Robert J. "Handbooks: History of a Genre." Rhetoric Society Quarterly 13.2 (1983): 87-98.

Dreyer, Benjamin, Dreyer's English: An Utterly Correct Guide to Clarity and Style, Random House, 2019.

Giroux, Henry, Neoliberalism's War on Higher Education, Haymarket Books, 2014.

Halttunen, Karen. Confidence Men and Painted Women: A Study of Middle-Class Culture in America, 1830-1870. Yale University Press, 1982.

Howard, Rebecca Moore, Twitter, @rmhoward,"I introduced the topic in class today. I showed them the online 1st ed of *Elements of Style* \& explained the possibility that it could be categorized as one of the naturalized mechanisms of structural racism" Accessed 29 March18.

Inoue, Asoue, Antiracist Writing Assessment Ecologies: Teaching and Assessing Writing for a Socially Just Future, Parlor Press, 2015.

- Labor-Based Grading Contracts: Building Equity and Inclusion In The Compassionate Writing Classroom, The WAC Clearinghouse, 2019.

Kynard, Carmen, Vernacular Insurrections: Race, Black Protest and the New Century in Composition-Literacies Studies, SUNY Press, 2013.

Milroy, James and Lesley Milroy, Authority In Language: Investigating Standard English, Routledge, 1985.

Paoletta, Kyle, "A Style Guide For The One Percent," The Nation, Feb. 11, 2019, https://www.thenation.com/article/benjamin-dreyersenglish-clarity-style-guide-grammar-review/

Strunk, William Jr., and E. B. White, The Elements of Style, The Macmillan Company, 1959.

(oc) EY-NC-ND

ULIS D-Sorle
This work is licensed under a Creative Commons Attribution-Noncommercial-No Derivative Works 3.0 United States License.

This journal is published by the University Library System of the University of Pittsburgh as part of its D-Scribe Digital Publishing Program, and is cosponsored by the University of Pittsburgh Press. 